\title{
RECONCILIAR VIDA HUMANA, AMBIENTE E EVOLUÇÃO: uma perspectiva da teologia da criação
}

\section{Reconciling human life, ambient and evolution: a perspective of the creation's theology}

\section{Lina Boff}

Pós-Doutora pela Pontifica Universitas Gregoriana de Roma PUG, Professora de Teologia Sistemática do Curso de Bacharelado em Teologia e do Programa de Pós-Graduação em Teologia (mestrado e doutorado) da PUC-Rio, Professora do Instituto Teológico Franciscano de Petrópolis (ITF), Professora convidada no Antonianum de Roma. Rio de Janeiro, RJ Brasil, e-mail: linaboff@puc-rio.br

\section{Resumo}

Tenta-se mostrar que a criação tem como único sujeito Deus. A ação criadora de Deus quis revelar-se através da carne humana e manifestar, na história, “a Imagem do Deus invisível”, integrando, na obra de Cristo, a criação inteira. Em toda a extensão da história da salvação, que se prolonga na fé da comunidade primitiva, como testemunho de primeira grandeza, esta comunidade celebra o papel de Cristo na criação, como Filho de Deus e, por ter assumido a condição humana, a comunidade de fé anuncia a novidade do processo criacional em constante mutação. De Cristo recebemos o 
Espírito que vem do Pai, que fez de seu Filho Único, o doador desse mesmo Espírito, para que nos reconciliemos com toda a criação. Deste modo, o ser humano, como ser primordial, integrado à criação e reconciliado com ela, se protege das várias formas de arrogância antropocêntrica que tem como resultado, a crise de valores humanos e espirituais que vive, como também, este mesmo ser humano, participa da cruel agressão feita ao ecossistema.

Palavras-chave: Criador. Espírito. Cristo. Ecossistema.

\section{Abstract}

It tried to show that the creation have God like only subject. The Creator action of God wants manifest itself through of the Human flesh and to manifest, in history, "the image of the Invisible God", integrating, in Christ's work, the whole creation. In all the extension of the Salvation's history, that if prolongs in the faith of the primitive community, like testimony of first magnitude, this community celebrates the Christ's function, like God's Son and, for he to have assumed the Human condition, the faith's community announces the novelty of the creational process in constant mutation. From Christ we received the Spirit that comes from Father, that doed of his Only Son, the donor of this same Spirit, towards we reconcile us with it, protect itself of the various forms the Anthropocentric arrogance that has like result, the crisis of Human values and spirituals that live, like well, this same Human being, participates of the cruel aggression made to ecosystem.

Keywords: Creator. Spirit. Christ. Ecosystem.

\section{Notas introdutivas}

Para se falar da urgência de reconciliar vida humana com seu ambiente em constante evolução, devemos nos inserir no contexto das atuais discussões sobre a responsabilidade de um desenvolvimento que, pode-se dizer, consciente dos resultados de colocar no centro da atual cultura globalizada, interesses econômicos e competitivos na escalada do ter, cria uma cultura antropocêntrica que ainda continua dominando toda a criação à custa do próprio ser humano em questão. É o grande paradoxo da nossa atualidade.

Rev. Pistis Prax., Teol. Pastor., Curitiba, v. 1, n. 2, p. 317-338, jul./dez. 2009 
O ser humano revestido da vocação a exercitar o “domínio” sobre a terra, exerce seu poder explorando-a através da ciência e da técnica, chegando assim à violenta degradação do ambiente. No debate bem conhecido, é preciso resguardar-se, porém, dos nostálgicos retornos aos modelos de cultura cosmocêntrica já superados em definitivo e da ideia de que o ser humano sozinho é o centro da criação.

A perversão do modo como se está tratando do cosmo e do ser humano em confronto do mundo como natureza, está sendo envolvida de maneira inquietante, a mesma fé cristã. Apresenta-se assim a exigência de que se respeite a estrutura de uma forma cristã de pensamento, evitando formulações puramente racionais e uma compreensão genética do mundo de tipo científico.

Antes de tudo, deve-se levar em conta a concepção que se tem de vida humana em seu sentido estrito e em seu sentido mais largo. Adotamos um critério regulado pela exigência de que se respeite a estrutura de uma forma cristã de pensamento sobre a criação do ser humano e de todas as coisas que a ele dizem respeito. Essa estrutura manifesta a vida de relação de toda a criação e fala de Deus como Comunidade relacionada na riqueza da diferença. Em seu tratado sobre o Espírito Santo, em torno aos anos 370, o padre da igreja, Basílio de Cesaréia da Capadócia, afirma: O Pai é o motivo que antecede; o Filho o motivo que cria; o Espírito o motivo que leva ao cumprimento.

O nosso propósito vem ancorado na fé de que reconciliar vida humana com o ambiente em que vivemos e a evolução que se faz presente de forma constante, seja no ser humano, como no ecossistema onde vive, é o assunto colocado em foco, neste momento, para todas as ciências, e de modo pertinente e relevante, para a Teologia.

\section{No princípio era Deus, o criador}

A criação tem como único sujeito Deus e faz parte da história salvífica em toda a sua extensão, pois narra as vicissitudes da história do povo de Israel, passa pela missão dos profetas que emprestam sua voz e sua boca a Javé, alertando o povo sobre o modo como organizavam sua vida sem o devido respeito e atenção para os bens oferecidos pela natureza. O profeta fala ao povo numa linguagem figurativa (REIMER, 2006, p. 37-39), dizendo que eles se juntaram para ocupar os vales com carros de guerra, invadiram as cidades com cavalos e armas de fogo

Rev. Pistis Prax., Teol. Pastor., Curitiba, v. 1, n. 2, p. 317-338, jul./dez. 2009 
para se defenderem do inimigo, uniram-se para construir diques e levantar muros com o fim de guardar a água e prover seus víveres. Mas não se voltaram para aquele que criou os vales, o lugar aprazível da cidade, os grãos para o sustento e água para a conservação da vida; e nem levantaram seus olhos para aquele que há muito tempo planejou todas estas coisas em função da vida e da paz (Is 22). Por isso a obra criadora de Deus entra em tensão com a resposta de infidelidade do ser humano, criando, assim, o drama histórico do pecado.

A teologia encontra resposta para esse drama no evento da encarnação, vida, morte e ressurreição de Cristo, momento culminante no qual o Projeto de Deus atinge sua realização e o drama da infidelidade do ser humano encontra a sua solução. A teologia parte, portanto, de Cristo para chegar a um Deus relacionado como Comunidade de amor e que atua pelo seu Espírito no Filho, para reconciliar a humanidade e toda a criação com Deus.

A perspectiva teológica da criação exige aqui que se abra um horizonte trinitário, pois é na identidade trinitária que se encontra o fundamento teológico da criação como realidade autônoma do mundo (BOFF, 1986, p. 14-15) e faz das muitas histórias de distintas culturas uma única história, que é história da salvação (AMATO, 1993, p. 273). Esta encontra no evento da encarnação, da cruz e da ressurreição, o momento no qual o projeto salvífico do Pai atinge a sua realização plena: a salvação de toda a humanidade.

Neste horizonte, enfatiza-se a atuação trinitária como Comunidade relacionada no amor pela comunhão gerada no Espírito Santo e revelada pela vinda de Jesus Cristo no meio de nós. Falamos desta Comunidade, mais conhecida como Santíssima Trindade, começando por Jesus Cristo porque é por Ele que temos acesso ao mistério de Deus Pai, de Deus Filho e de Deus Espírito Santo. ${ }^{1}$

Na identidade trinitária está o fundamento da possibilidade mesma da criação, como realidade na qual vivemos e nos movemos, e realidade em evolução. A posição do ser humano nesta evolução da teologia da criação é a de ser uma pessoa aberta e dialogante com seu Criador que a interpela. É deste diálogo feito na liberdade, que nasce e se constrói a história da salvação.

O mundo tem uma consistência de espaço e de tempo que não podem ser dissolvidos na liberdade do homem. Por isso, se não há possibilidade do

1 Confrontar com Basílio ao escrever seu tratado sobre o Espírito Santo, in Dicionário Patrístico e Antiguidades Cristãs da Paulus, 2002, p. 215; "Sobre o Espírito Santo", 31d, PG 32, 136.

Rev. Pistis Prax., Teol. Pastor., Curitiba, v. 1, n. 2, p. 317-338, jul./dez. 2009 
mundo sem o homem não há possibilidade do homem sem o mundo (BINGEMER; FELLER, 2003, p. 142-143). Mas não existe ser humano possível sem o eterno Filho de Deus e não existe, de fato, historicamente a sua criação e salvação, sem o Filho eterno encarnado pela força do Espírito que desce numa mulher quando chega à plenitude dos tempos $(\mathrm{Gl} 4,4)$. A fé na criação nasce da manifestação histórica de Deus em Jesus Cristo, através da palavra e o seu Espírito. Este fato histórico é a substância insuperável da fé no Deus Criador de todas as coisas.

\section{Em Cristo a primeira criação se completa}

A doutrina que Paulo nos apresenta sobre o primado de Cristo na criação, é um testemunho de primeira grandeza da fé primitiva que celebra e proclama a preexistência divina de Jesus Cristo, num Hino, que é também uma efusão do coração, uma troca de notícias e uma advertência do apóstolo à comunidade de Colossas. Em nota de pé de página, seguem alguns elementos de contextualização do texto hínico. ${ }^{2}$

2 VANNI, 1995, p. 295-299. Segundo os últimos estudos feitos, a comunidade de Colossas não foi evangelizada por Paulo. Seu representante, Epafras, trouxe-lhe informações pouco promissoras da caminhada de fé de seus membros: estão tendo sérias dúvidas que provêm de especulações do judaísmo, e fortemente influenciadas pela filosofia helenística que atribuíam aos poderes celestes o comando e o ritmo do cosmos, da natureza, da criação, comprometendo o lugar e a função de Cristo na criação divina, numa palavra, a supremacia de Cristo. Ao ser alertado, Paulo responde com uma carta na qual organiza sua doutrina em função da resposta que deve dar à polêmica suscitada pelos membros desta comunidade. Paulo até assimila os poderes celestes - motivo de contenda e polêmica na comunidade - e os recoloca no seu devido lugar, que é o grande plano da salvação. Fala-lhes da nova ordem instaurada por Cristo, o Kyrios, o Senhor, que como Imagem do Pai trouxe a nova criação, na qual Ele assumiu a Plenitude - o pleroma - do ser, de Deus e do mundo em Deus. O Primado de Cristo está colocado na ordem da criação natural e na ordem da nova criação. Por isso explica e precisa bem a extensão cósmica da obra de Cristo, a dilatação da obra da salvação pelo sangue da sua cruz. Tudo indica que, nesta insistência mais forte de Paulo à comunidade em crise, ele está falando de uma escatologia já realizada no presente com a vinda de Cristo morto-ressuscitado. Em tal contemplação suprema, muito bem expressa neste hino de caráter, pode-se dizer, quase litúrgico, Paulo apresenta o Corpo de Cristo na figura da Igreja, que deve estar atenta à dilatação cósmica da obra da salvação que se atua na relação não só entre os humanos, mas com a natureza criada pelo Criador.

Rev. Pistis Prax., Teol. Pastor., Curitiba, v. 1, n. 2, p. 317-338, jul./dez. 2009 
Ele é a imagem de toda criatura, porque nele foram criadas todas as coisas, nos céus e na terra, as visíveis e as invisíveis, Tronos, Soberanias, Principados, Autoridades, tudo foi criado por ele e para ele. Ele é antes de tudo e tudo nele subsiste. É a Cabeça da Igreja que é seu Corpo. É o Princípio, o Primogênito dos mortos, tendo em tudo a primazia, pois nele aprouve a Deus fazer habitar toda Plenitude e reconciliar por ele e para ele todos os seres, os da terra e os dos céus, realizando a paz pelo sangue da sua cruz. $(\mathrm{Cl} 1,15-20)$.

Afirmações de peso encontram-se neste Hino. Em primeiro lugar, a ação criativa típica de Deus se inspira em Cristo, Primogênito de toda a criação. Aparece mais clara, então, a dimensão cosmológica, antropológica e soteriológica da criação. Cristo seria como o fio unificador da criação-criada, maneira imprópria de expressão. O texto afirma, ainda, que Cristo, como ponto de partida, inspirador da ação criadora, é antes de todas as coisas. A sua presença aglutinante em todas as coisas criadas, confere a elas uma coesão, e as coisas na sua universalidade, mantêm a própria consistência em relação a Cristo. O Hino desta comunidade primitiva segue afirmando que o papel de Cristo na criação compreende a função da força reconciliadora que deriva de seu mistério pascal. Este constitui um dos aspectos inseparáveis entre Cristo e toda a realidade criada, pois Ele é o princípio, portador da plenitude realizada - o pleroma - ponto de chegada de todas as coisas.

Por fim, a criação é motivo de louvor que se prolonga no Novo Testamento e atinge sua completude quando assume nossa condição humana no Mistério da Encarnação. Instaura-se então, a nova ordem: o Cristo, o Kyrios, assume o serviço de presidir o governo do mundo (Fl 2, 6-11). Fica claro que esta comunidade celebra o papel de Cristo na primeira criação - Gênesis - e na nova criação - trazida por Cristo com seu Mistério pascal. Enfatiza ainda que, em Cristo, a ação criadora de Deus pôde manifestar-se e expressar-se de modo excelso, através da carne humana e suscitar, portanto, na história, “a Imagem do Deus invisível” (Cl 1,5). Paulo dilata suas ideias teológicas integrando na obra de Cristo toda a criação.

O ponto fundamental da doutrina da criação aqui exposta nos motiva também a ler o primeiro capítulo do Gênesis à luz do Prólogo de João. Em Gênesis 1 lemos que: No princípio Deus criou a terra e as águas, as ervas que dão sementes, as árvores que dão frutos; criou o dia e a noite, os seres vivos da terra e do mar, as aves aladas, as feras e os animais domésticos, .... Deus viu que isso era muito bom, que tudo era coisa boa. A teologia que é fé, responde com o Prólogo de João:

Rev. Pistis Prax., Teol. Pastor., Curitiba, v. 1, n. 2, p. 317-338, jul./dez. 2009 
No princípio era o Verbo e o Verbo estava com Deus e o Verbo era Deus. No princípio ele estava com Deus. Tudo foi feito por meio dele e sem ele nada foi feito. $O$ que foi feito nele era a vida, e a vida era a luz dos homens; e a luz brilha nas trevas, mas as trevas não a apreenderam. (Jo 1,1-5).

Esta é mais uma das leituras que a teologia pode fazer da criação que envolve o ser humano, seu ecossistema e a evolução concebida no seu significado englobante. Jesus Cristo nos revela essa "plenitude da graça e da verdade”, manifestadas no prazer e na benevolência com que Deus nos dá a conhecer seu mistério em seu Filho. Tal mistério é o derramamento, em cada um de nós, daquele mesmo dom de graça e de sabedoria que são plenificadas em Cristo (Ef 1,9).

A interpretação feita neste âmbito valoriza o mundo, como natureza, o ser humano como criatura primordial, no sentido de que cada um de nós não é só espírito-liberdade-consciência, mas também corpo que está no mundo, que pulsa com ele. Esta dimensão de estar-no-mundo, é hoje recuperada como dado fundamental, dentro da teologia da criação, porquanto diz respeito à relação entre Cristo como Primogênito de toda a criatura e o significado que o ecossistema e a evolução têm, para a vida humana.

A protologia criativa do cosmo exprime de fato, no "princípio" (en arché), não só um início da história da salvação, mas também um "início" sapiencial em que a Sabedoria Criadora do Pai se apresenta personificada na linguagem poética desenvolvida em Israel após o exílio, apresenta a Sabedoria criadora como pessoa, que na interpretação da tradição e da exegese, é a Palavra ou o Espírito. Assim se expressa o autor sagrado: “Javé me criou, primícias de sua obra, de seus feitos mais antigos. Desde a eternidade fui estabelecida, desde o princípio, antes da origem da terra” (Pro 8,22-23).

[...] quando punha um limite ao mar, e as águas não ultrapassavam o seu mandamento, quando assentava os fundamentos da terra. Eu estava junto com ele como o mestre-de-obras, eu era seu encanto todos os dias, todo o tempo brincava em sua presença: brincava na superfície da terra, e me ale grava com os homens. (Pro 8,29-31).

No Novo Testamento, é retomada e aplicada à pessoa de Jesus Cristo que participa, desde a fundação do mundo, da criação e da sua consistência. 


\section{No espírito, Deus se faz comunidade de reconciliação}

Esta reconciliação vem pelo Espírito, que põe em movimento a obra do Criador e cria a comunidade de fé. ${ }^{3} \mathrm{O}$ evento da encarnação traz consigo a irrupção do Espírito, que, na história salvífica, não se fecha num presente temporal, mas realiza a promessa eterna que entra no tempo. Assim, o Espírito que suscita no coração da humanidade redimida, o gemido que se dirige ao cumprimento da adoção filial (Rm 8,23), é ainda o mesmo Espírito que suscita a espera impaciente da criação toda pela revelação dos filhos e filhas de Deus $(\mathrm{Rm} 8,19)$, em vista da sua completude (Rm 8, 19-22).

O espírito se encontra já no início de tudo e o livro do Gênesis diz que o espírito de Deus pairava sobre as águas quando Deus criava o céu e a terra (Gn 1,2). Ele perpassa toda a criação, movimenta todos os pontos de mutação do cosmo até na sua mais perfeita expressão que é o Espírito divino, mais tarde, o Espírito Santo. O cosmo como um todo é criação do espírito; o mundo material por nós considerado inerte é movido no espírito e pelo espírito; animais e plantas são penetrados pelo espírito em todas as suas energias. Nós, os humanos, somos considerados portadores do espírito humano, porque nos abrimos à comunicação, à inventividade e ao serviço ao outro e à outra.

A nossa comunicação e abertura a Deus, como sentido profundo da vida, é feita pelo espírito humano que trazemos dentro de nós. E é o espírito humano que nos leva à comunicação com o Espírito divino, ou o Espírito Santo, Espírito de Luz. Esse Espírito define a identidade de Deus que se revelou em Jesus Cristo na nossa condição humana. O Espírito Santo não é uma realidade criada pela nossa imaginação, mas uma realidade divina que nos leva a fazer a experiência de comunhão com Deus e com toda a criação, plasmada por Ele. O Espírito Santo é uma Pessoa.

Na luz trinitária do evento cristológico, o Espírito é o escatológico em Deus (MOLTMANN, 1999, p. 101), não só enquanto funda a abertura do amor trinitário de Deus em direção ao ser humano. Mas também quando o ser humano se abre para a plenitude do Espírito que habita a criação. Esse ato de abertura ao Espírito intensifica ainda mais a esperança que está em nós, porque não só nós humanos, mas a criação inteira geme e sofre as dores de parto, suplicando ao Espírito que socorra a nossa fraqueza (Rm 8,22.26).

3 Para isso ver BOFF, 2003, p. 153-160.

Rev. Pistis Prax., Teol. Pastor., Curitiba, v. 1, n. 2, p. 317-338, jul./dez. 2009 
No âmbito da criação, o ser humano é concebido como criatura primordial por ser dotado de liberdade, consciência e espírito (BOFF, 1995, p. 248); por ser livre, leva a cumprimento a palavra da criação; por ter consciência de seus atos, se protege das várias formas de arrogância antropocêntrica, até mesmo da interpretação bíblica da criação: “[...] enchei a terra e submetei-a, dominai-a [...]” (Gn 1,28); finalmente, por ter seu espírito aberto ao Espírito Criador do Pai, busca o sentido perdido da profundidade da vida e descobre seu lugar no mundo criado (AUER, 1987, p. 208-209). Coroamento da criação, porém, não é o homem e a mulher, mas o sábado. ${ }^{4} \mathrm{O}$ sábado atualiza a Aliança que Javé faz com toda a criação, que se completa com a criação do "homem à sua imagem, à imagem de Deus ele o criou, homem e mulher ele os criou" (Gn 1,27).

O espírito legalista transformou a alegria do sábado numa observância sem sentido, da qual Jesus libertou seus discípulos, quando estes, com fome, comeram espigas arrancadas; e criticados por esta ação, Jesus se coloca como Senhor do sábado (Mc 2,27s). O sábado atualiza, ainda, a ação salvadora e criadora de Javé, que chama, constantemente, o homem e a mulher de todos os tempos, a viverem a interação com tudo o que Deus criou e plasmou no amor e na liberdade de sua onipotência.

A excelência do sábado não desclassifica, não diminui o valor central do ser humano no mundo: "O sábado foi feito para o homem [...]" (Mc 2,27), mas deve-se considerar o sábado do Deus Criador no seu exato sentido, e interpretá-lo em relação a Cristo, Senhor do sábado. Com a vinda de Cristo no meio de nós, abre-se o tempo sabático que é a atualização da senhoria de Deus no mundo como tempo de misericórdia: "Quero misericórdia e não sacrifício [...]” (Mt 12,7). O ser humano pode considerar-se o sábado de Deus, dimensão sabática que atravessa toda a criação enquanto espelho da glória de Deus.

Se a doxa divina se concentra, de modo primordial, na criação do homem e da mulher à sua imagem e semelhança (Gn 1, 26-27), esta afirmação passa pela consciência que vem do Espírito, e pela prática que exige do homem e da mulher, hoje, uma ação urgente e inderrogável: esta ação consiste em

4 Porque em seis dias Javé fez o céu, a terra, o mar e tudo o que eles contêm, mas repousou no sétimo dia; nesse dia Javé santificou o dia do sábado, pois nesse mesmo dia ele fez uma aliança eterna com toda a criação (Êx 20,11), como sinal perpétuo entre Javé e os filhos de Israel (Êx 31,17). Faça também um consulta com MOLTMANN, 1986, p. 46.

Rev. Pistis Prax., Teol. Pastor., Curitiba, v. 1, n. 2, p. 317-338, jul./dez. 2009 
reconciliar a vida humana com seu ecossistema e com a evolução das leis que determinam a natureza de cada ser criado por Deus. Não basta a evolução humana, torna-se necessário o respeito pela evolução das leis de toda a criação que dá condições de vida das nações sobre a terra. Entre os seres vivos, o ser humano se diferencia radicalmente dos demais, pela capacidade que tem de reagir ao mundo e de refletir de forma consciente sobre seus atos. É assim que as sociedades humanas fazem sua própria história. A natureza também tem sua própria história, mas é uma história que nós contamos (BOFF, 1995, p. 139).

Nesse contexto, cabe levar em conta as implicações que a fé cristã nos coloca diante da luta pela satisfação das muitas necessidades que o ser humano, hoje, apresenta. A experiência de se criar uma nova cultura que gere um novo modo de pensar e agir no trato com a natureza, exige conciliar vida humana, ecossistema e evolução. Tal proposta não pode ser vista dissociada de uma nova criação em seu significado de vida humana e espiritual, uma vida reconciliada com tudo e com todas as coisas criadas, numa palavra, a vida nova da nova criação trazida por Cristo. Essa proposta nos coloca sérias implicações que exigem abertura ao Espírito e disponibilidade no seguimento e na participação da vida de Cristo em seu mistério, para uma sadia vida cósmica, antropológica e teológica.

\section{No nível cósmico}

À luz da fé cristã, não é compreensível uma transformação radical da corporeidade humana em corpo de glória, sem a transformação do mundo. A criação do ser humano é essencialmente ligada ao ato constitutivo do mundo, como sua dimensão intrínseca. Deste modo, a primeira criação do Gênesis e a nova criação trazida por Cristo encontram a sua realização plena, no mundo, e este constitui parte integrante dos novos céus e nova terra (BORDONI, 1995, p. 610-611).

O ser humano não encontra o sentido de sua existência só nas perguntas temporais da sua origem e do seu fim. Ele tem necessidade também de um espaço, de um oikós para reencontrar-se a si mesmo. Sem estar situado se desorienta. É no espaço que ele sente a necessidade de encontrar aquela dimensão de tempo para recuperar suas forças; é o tempo cósmico que se manifesta na natureza feita de ciclos, de diferentes estações. Assim, a transfiguração da vida

Rev. Pistis Prax., Teol. Pastor., Curitiba, v. 1, n. 2, p. 317-338, jul./dez. 2009 
será realizada não só pelo escandimento dos momentos temporais (kairoi), mas também pelo estar-no-mundo como lugar de encontro (TRIGO, 1988, p. 165166). Deus mesmo precisou de lugar e espaço cósmico como natureza, para se revelar à humanidade, entregar seus mandamentos de vida e fazer seus encontros com o povo que amava.

O mundo como natureza é lugar da presença de Deus, via de comunicação da sua revelação e da sua glória. Na história da salvação encontramos tempos e lugares das teo-fanias: Bethel, o Sinai, a Tenda, o Templo. A montanha aparece, frequentemente, como o lugar preferido por Javé quando quer revelar-se a seu povo. Pede a Moisés que suba a montanha para selar Aliança com seu povo (Êx 24). E isto acontece no Novo Testamento também. Jesus faz seu discurso inaugural sobre as bem-aventuranças na montanha próxima a Cafarnaum (Mt 5).

No contexto do Novo Testamento, ainda mais o cosmo é assumido como o lugar por excelência do drama da salvação que desemboca na feliz realização da promessa e da manifestação da glória divina em carne humana. É no mundo que vem a luz (Jo 3,19), é ao mundo que Jesus deve revelar-se a Jerusalém (Jo 7,4), é o mundo que Ele atrairá a si quando elevado da terra. A concorrida entrada messiânica de Jesus em Jerusalém confundiu a cabeça dos fariseus que chegaram a comentar entre eles, em tom de fracasso: "Vede, nada conseguimos. Todo mundo vai atrás dele” (Jo 12,19).

Ora, se o Verbo eterno se encarna no tempo e no espaço cósmico, ele transfigura tais dimensões da criação, fazendo delas uma via de comunicação do mistério eterno de Deus. Para o evangelista João, as relações de Cristo com o espaço humano e terrestre, a sua aparição numa área geográfica determinada, a sua habitação entre nós, os seus gestos, a sua elevação da terra, segundo o realismo da expressão joanina, a sua descida a nós, como sacramento da sua carne dada em nutrimento (Jo 5-6), significam e realizam a inserção no mundo de uma presença que transcende o mundo e opera a elevação da humanidade à vida divina que assume a vida humana para transformá-la. As realidades do mundo do alto estão lá, mas presentes e operantes também aqui. ${ }^{5}$

A efetivação dessas realidades, na sua dimensão cósmica, deve ser vista e apreendida, não só como realização do mundo cósmico como tal, como

5 Para ampliar esta compreensão, indica-se o artigo da autora, "A fé na comunhão dos santos", BOFF, 2004, p. 30ss.

Rev. Pistis Prax., Teol. Pastor., Curitiba, v. 1, n. 2, p. 317-338, jul./dez. 2009 
foi criado, e como o interpretamos nós; mas deve ser visto e vivido na sua interação com a obra histórica da pessoa humana e o agir de Deus (REIMER, 2006, p. 86). Os novos céus e a nova terra serão o reflexo da obra humanizadora e a imagem de Deus, que é o ser humano refletida no mundo. Tudo isso representará o máximo da glória divina trinitária.

A criação como cosmo não é simples cenário ornamental da relação direta e interpessoal entre Deus e a pessoa humana. Esta constitui um importante lugar de mediação desta relação. Se for verdade que Cristo, na sua pessoa encarnada é o Mediador (1Tm 2,5), ou o lugar da mediação, sua função se plenifica no mundo, na criação assumida e transfigurada (Rm 8,19ss). A transfiguração do mundo no evento cristológico da encarnação coroada pela ressurreição é encontrada em Cristo. Nele "aprouve a Deus fazer habitar toda a Plenitude” (Cl 1,19), o “pleroma”, que, num contexto sapiencial, é indicativo da plenitude do cosmo transfigurado (Sb 7,22). Por isso, podemos afirmar que "a prometida restauração que esperamos já começou em Cristo é levada adiante pela ação do Espírito Santo”, enquanto nós, na esperança, realizamos a obra que o Pai nos entregou (LG 48). ${ }^{6}$

Ao aplicar à vida de fé o conceito cristão de salvação do mundo, a reflexão teológica foi, não raras vezes, dominada pelo protagonismo dado ao ser humano em sua relação com Deus e nada mais. Como se Deus não levasse em conta sua criação - o mundo, a natureza, as coisas. Nesse âmbito, a Teologia deverá recuperar a importância da mediação cósmica e do papel simbólico do mundo. Tanto mais que esse papel vem sendo hoje, colocado mais claro nos dados provenientes das ciências da vida e da própria comunicação das descobertas feitas em todos os âmbitos da interdisciplinaridade e da transdisciplinaridade.

Enfatiza-se, aqui, a capacidade que é dada à pessoa humana de entrar em diálogo com Deus Criador, que se dá a conhecer na pessoa de Jesus Cristo. É a relação da condição humana limitada que entra em diálogo com o Transcendente e Eterno. Nenhuma das coisas criadas entra na dimensão dialógica com o Senhor que as criou. Só ao homem e à mulher, criados à imagem e semelhança de Deus, são dados a capacidade desta relação com seu Criador. É a nova criação encarnada.

6 Para mais ampla compreensão, ver artigo da autora, "A Spe salvi sugere o Vaticano II? Do Continente da Esperança", BOFF, 2008, p. 656s.

Rev. Pistis Prax., Teol. Pastor., Curitiba, v. 1, n. 2, p. 317-338, jul./dez. 2009 


\section{No nível antropológico}

A evidência, neste parágrafo, está colocada no ser humano como ser pessoal, que, na liberdade, entra em relação de diálogo com o evento revelado, que é a autocomunicação do amor de Deus na nova criação, realizada no mistério pascal de Cristo. Criado como partner de Deus, o ser humano entra em diálogo com Deus Pai, na condição de criatura; com Jesus Cristo, na condição de redimido; e com o Espírito Santo, na condição de pessoa reconciliada com todas as coisas. Neste diálogo, o ser humano tem a liberdade de dizer "sim" ou dizer "não" à proposta divina. Iniciam-se o drama da história da salvação que Cristo, com seu mistério pascal, dá uma resposta cabal, superando o fechamento do ser humano ao dom de Deus, para criar o homem novo e fazer novas todas as coisas relacionadas a ele, apagando-lhes, de uma vez por todas, a mácula do pecado.

A direção para a qual se projeta a nova criação constitui, não só a confirmação de um mundo novo já no presente, mas rompe os limites da condição terrena ligados à vida biológica em corpo mortal, para projetar a glória do Cristo, testemunhada na pessoa humana e em toda a criação. A nova criação, portanto, põe em relevo a gratuidade do projeto do Pai em Cristo, que mostra a essencial relevância do ser humano como pessoa que entra em mútua relação do querer de Deus. Este se cumpre na livre e histórica acolhida, na fé, que inclui toda a existência do ser humano como ser capaz de dialogar com Deus que the faz a proposta de salvação.

Aqui se encontra o grande alcance da resposta humana ao projeto divino. A pessoa é considerada capaz de estabelecer essa relação não como sujeito ad extra, mas como sujeito ad intra que, nessa comunicação com Deus, na sua dimensão trinitária, faz história, porque a pessoa realiza o querer de Deus em Jesus Cristo. ${ }^{7}$ A autocomunicação de Deus em Jesus Cristo, remonta, portanto, à livre acolhida histórica da fé, do ser humano, o qual comporta a sua existência de relação dialógica de comunhão com o ser de Deus, como Comunidade relacionada no amor. A história, por obra do evento cristológico, já realizada na nova criação sob a ação do Espírito, envolve, de modo particular, a pessoa humana como criação primordial e como ser do mundo, encarnado essencialmente, no corpo (COMBLIN, 1990, p. 261-268).

Ver também DIANICH, 1992, p. 28-41.

Rev. Pistis Prax., Teol. Pastor., Curitiba, v. 1, n. 2, p. 317-338, jul./dez. 2009 
BOFF, L.

Deste modo, a pessoa humana introduz na realidade do mundo da criação aquele suplemento de alma e de graça, pelas quais não só a criação se faz história, mas se faz tempo em que a Sabedoria que vem do alto dá ao ser humano o conhecimento do cuidado e do zelo, da criação como cosmo e como vida humana. As coisas que servem à vida, não podem perecer, mas devem ser cuidadas para que, junto com os humanos, bendigam e proclamem a glória do Deus Criador (Sl 104).

A direção para a qual se projeta a nova criação constituirá, de fato, não só a confirmação de um mundo novo já no presente, mas constituirá a realização das instâncias humanas e cristãs de uma corporeidade que já agora, pela encarnação salvadora de Cristo, supera os limites da condição terrestre ligados à vida biológica em corpo mortal, mas projeta na sua corporeidade, a glória do Cristo, pela conformação a Ele, no mistério da Páscoa eterna. A aspiração à redenção do corpo da qual Paulo nos fala em seu capítulo 8, escrevendo aos Romanos, vai além da pergunta antropológica de realização da identidade da pessoa humana enquanto encarnada. Sim, porque a vida nova da pessoa humana em Cristo, como ato do encontro entre ontologia criadora e história salvadora, sublinha aquele caráter cristocêntrico da nova criação, que consiste na participação da pessoa humana à glória do Cristo da fé, no seu próprio corpo.

A concepção mesmo do agir revelador de Deus, na nova criação, como oferta gratuita da própria autocomunicação de amor, realizada no evento da cruz e ressurreição de Cristo, implica estruturalmente, um sujeito ad extra, que é o ser humano capaz de uma resposta que acolhe o chamado à liberdade. ${ }^{8} \mathrm{O}$ discurso que se faz da nova criação coloca em evidência a realização do projeto do Pai, em Cristo. A evidência neste parágrafo foi colocada na pessoa humana que interage com seu Criador a partir de toda a criação, viva e inerte, pois em Cristo tudo foi restaurado. Quando se fala de Novos Céus e Nova Terra, formulase a realização plena do princípio-esperança trazido pela ressurreição de Jesus, que fez novas todas as coisas. N'Ele o propósito divino do Pai é consumado, ${ }^{9}$ isto é, a matéria humana e a cósmica entram na vida de Deus como Comunidade relacionada pelos laços do Amor.

8 BORDONI, em sua conferência "L'orizzonte cristocêntrico della creazione..." (apud SESBOÜÉ, 1991, p. 421).

9 Significa dizer que a matéria entra no espírito de Deus, transforma-se em uma identidade gloriosa.

Rev. Pistis Prax., Teol. Pastor., Curitiba, v. 1, n. 2, p. 317-338, jul./dez. 2009 


\section{No nível teológico}

Na dimensão teológica, diretamente referida à experiência de fé, pensamos em colocar o ponto de partida do discurso sobre a criação, no coração do movimento da cristologia eclesial - a cristologia elaborada pela experiência das comunidades apostólicas, experiência atualizada pelas comunidades até nos nossos dias. A cristologia eclesial ${ }^{10}$, nas suas fases de desenvolvimento, evidencia o agir criador de Deus em Jesus Cristo. Esta experiência parte da celebração pascal da nova criação projetada em direção à vida plena, para remontar ao horizonte protológico, como primeiro momento de livre projeção e realização do propósito originário do Deus Criador de todas as coisas, que se revela no Filho.

Quando falamos de horizonte protológico, estamos fazendo o discurso referente à criação inicial, que percorre todo o caminho da história da salvação, até sua realidade última, que é a escatológica, realidade trazida pela ressurreição de Cristo. A realidade primeira e a realidade última se reclamam e se identificam, mediadas pela história. O discurso teológico referente à criação trazida por Cristo é pelas comunidades apostólicas. Estas descobriram a dimensão da nova criação nas reuniões celebrativas testemunhado comunitárias que faziam.

O gênero literário contemplativo e, pode-se dizer, litúrgico que encontramos em muitas Cartas de Paulo às comunidades do tempo dos apóstolos representam a cristologia mais viva que se pode encontrar no Novo Testamento. Veja-se, por exemplo, o Hino quase litúrgico da comunidade de Colossas, em 1, 15-20, que apresentamos no início. Seguindo a mesma inspiração, veja-se também outro Hino, igualmente, quase litúrgico, proclamado pela comunidade dos Efésios, ${ }^{11}$ em 1, 3-14; Paulo ou sua escola, aqui, dirige seu olhar contemplativo para a reconciliação dos povos; deixa transparecer a mística que pervade todo o mistério da salvação e cria coisas novas com a plenitude da vida

\footnotetext{
10 Ver BOFF, Leonardo 1972, p. 80-85; 135-147.

11 Dizionario Bíblico storico/critico, a cura di FABRIS, 1987, p. 301-302. Éfeso é uma grande cidade da costa da Ásia Menor, beneficiada por uma terra agrícola extensa e fértil. Esta Carta de Paulo aos efésios é, particularmente, importante pela sua doutrina. A perícope a que nos referimos, 1, 3-14, constitui uma Bênção, que apresenta como centro a palavra "mistério", palavra-chave da perícope introdutiva da Carta. Esta palavra significa a obra da salvação realizada por Cristo como Cabeça de todo o universo, que manifesta as dimensões cósmicas da salvação.
}

Rev. Pistis Prax., Teol. Pastor., Curitiba, v. 1, n. 2, p. 317-338, jul./dez. 2009 
de Cristo já realizada com sua ressurreição. Termina esta perícope, afirmando que, em Cristo, fomos escolhidos antes da fundação do mundo para sermos santos e reconduzir todas as coisas a Deus, Pai de Nosso Senhor Jesus Cristo, que nos doou seu Espírito de vida (Ef 1, 1-2).

Do ponto de vista da fé neotestamentária, o horizonte teológico é aquele que ilumina e guia todo o discurso sobre a criação. Tal discurso se propõe colocar em destaque o lugar primordial do ser humano como parte integrante e integrada de toda a criação. Deste pensar iluminado pela fé, o discurso teológico não descuida do zelo que a humanidade deve exercer para com todo o ser que tem vida, seja ela dinâmica ou inerte. A fé pensada nesse processo tem como significado pleno o do evento teológico em que se manifesta a comunicação da vida trinitária de Deus ao ser humano. ${ }^{12}$

É neste evento que se estabelece a íntima relação que existe entre salvação e criação: a criação se revela como um ato de salvação e esta se realiza como a nova criação, no dom da autocomunicação de Deus como Pai, como Filho e como Espírito, o qual dá testemunho da nossa fé na ação criadora do Pai. A obra criadora de Deus atinge sua realização plena em Cristo, fazendo da história do homem, Jesus de Nazaré, não só um lugar pessoal da definitiva revelação de Deus, mas também o lugar de encontro entre esta revelação e a resposta da liberdade da pessoa humana. No mistério da encarnação, que se completa no mistério pascal, se opera, temporalmente, a síntese da verdade ontológica da criação assumida por Deus e da verdade histórica da salvação. A nova criação que se define formalmente, como dom da vida trinitária, joga luz sobre todo o processo criador e criativo de Deus na pessoa de Jesus Cristo.

O ponto de vista da Escritura neotestamentária que remonta à primeira criação, o faz a partir do dado de fato da segunda criação - a criação realizada em Cristo. Tende, assim, a conglobar as duas perspectivas no quadro do único desígnio gratuito do Pai que, na ordem histórica presente - única tomada em consideração pelo autor sagrado - deliberou a primeira criação em vista da segunda. ${ }^{13}$

A perspectiva teológica caracteriza a visão bíblica da criação inseparável da história da salvação. Esta é determinada pelo sentido teológico

\footnotetext{
12 Ver também COLOMBO, 1977, p. 201-202. O problema teológico da criação aparece como o problema da possibilidade da comunicação do ser trinitário.

13 Ver também BORDONI, 1995, p. 725.
}

Rev. Pistis Prax., Teol. Pastor., Curitiba, v. 1, n. 2, p. 317-338, jul./dez. 2009 
da criação, como processo direcionado, a um telos final. É partindo do fim que se pode discernir a importância e o sentido do princípio. Esta perspectiva teológica da criação supera o quadro de uma ontologia estática e identitária, incapaz de integrar no ser criado o valor da história, para orientar a reflexão a uma ontologia da alteridade, que é o diálogo do ser humano com Deus.

O horizonte teológico que consente à teologia da criação de apresentar a relação entre o Criador e sua criatura, tempo e história, cosmo e ser humano, deve ser definido num contexto cristocêntrico. Neste, o teológico supera o limite do tempo que se conjuga ao pólo inicial da eternidade. ${ }^{14} \mathrm{Na}$ Bíblia, o Eterno é pensado como o princípio, o sentido e o cumprimento da história. Por isso, o teológico não pode ser pensado só em termos temporais: a noção de princípio e fim não são noções intratemporais, mas fundam suas raízes na eternidade de Deus. ${ }^{15}$

Em Cristo se dá a irrupção do eterno no tempo. É ele que conduz toda a criação à sua plenitude (consumatum est), enquanto a instância dinâmica da história, ligada ao dinamismo temporal do cosmo e da liberdade humana, na sua estrutura social, projeta a plenitude antecipadora, em direção a um ulterior cumprimento final da história (veniet consummatio).

É nesta perspectiva teológica, que se apresentam as dimensões essenciais da salvação que criam coisas novas (BOFF, 2000, p. 233-240), na medida em que a vida humana se reconcilia com o ambiente que ela mesma constrói e no respeito das leis da evolução que o ecossistema reclama. Um das maneiras que o ser humano tem de se reconciliar com Deus, com a sociedade e com o cosmo, como mundo ordenado que remete ao Deus Criador, é a prática da fé que se manifesta nas obras.

\section{Sintetizando para uma prática}

A doutrina bíblica da criação, tanto do Novo como do Antigo Testamento, não tem motivações e interesses cosmológicos, mas sim teológicos e soteriológicos. Os escritos bíblicos querem dar testemunho da fé do povo na

14 Ver AA.VV, 1995: a publicação apresenta, em seus vários autores, da aproximação metodológica na qual a teologia partilha a incerteza das distintas posições de estudiosos de renome internacional. As paginas por nós conhecidas seguem nesta nota, mas contam também com a nossa participação a este Congresso realizado na Itália: p. 14-56; 165ss; 220-225; 357-374.

15 Ver BORDONI, 1993, p. 72 e seguintes.

Rev. Pistis Prax., Teol. Pastor., Curitiba, v. 1, n. 2, p. 317-338, jul./dez. 2009 
BOFF, L.

ação salvadora e criadora de Deus no mundo e para além do mundo. Querem ainda louvar a esse Deus por seu cuidado com todas as criaturas. A crise ecológica de sobrevivência, cada vez mais aflitiva e que está conferindo à doutrina da criação, em curto espaço de tempo, grande atualidade, tem como objetivo primeiro, despertar a consciência humana para a obra criadora do Supremo Criador. Este despertar pode ser assimilado e praticado no nosso dia-a-dia. Motiva-nos a ter uma atitude humana diante de todas as coisas criadas e uma concentração de comportamentos éticos no trato com elas.

Tudo isso deve ser alimentado por uma abertura para a interdisciplinaridade do nosso conhecimento racional, através de parcerias, intercâmbios de saberes e diálogos competentes, da teologia com as outras ciências. Caminhar juntos nos parece a exigência do momento. Trata-se de consolidar e preservar os bens materiais em vista dos valores que dizem respeito à pessoa humana como um todo, sejam eles materiais ou espirituais e celebrativos, da criação da qual fazemos parte. Foi assim que Deus se acercou de nós, fez-se um de nós, para nos dar o sentido espiritual de sua encarnação.

Cabe a cada um e a todos, efetivarem uma mudança radical da consciência e do comportamento, sem os quais, a superação da crise é inconcebível. O tempo presente nos interpela e nos impulsiona ao compromisso em todas as dimensões da nossa vida, seja no âmbito político, social, cultural, religioso e, sobretudo, no grande espaço de solidariedade que nos cabe ocupar, sobretudo para com as massas excluídas e deletadas do planeta-terra.

\section{Celebrando a reconciliação da obra criadora do Pai}

A fé que celebra passa pela consciência que se tem da origem primeira de todas as coisas; se expressa no rito que manifesta as realidades silenciosas da fé e envolve todo o ser humano e o cosmo, seja através de uma linguagem verbal ou mesmo não-verbal. No processo de reconciliar a vida humana com seu ambiente e a evolução que caracteriza todos os seres criados, de modo primordial o homem e a mulher, o momento da ação salvífica do Deus Criador de tudo o que existe, se faz presente num rito que constitui a religião na qual a fé se expressa. O Cristianismo, portanto, nasce desses conteúdos brevemente,

Rev. Pistis Prax., Teol. Pastor., Curitiba, v. 1, n. 2, p. 317-338, jul./dez. 2009 
aqui apresentados e que, celebrados, fazem da teologia o ato mais profundo e sincero de louvação a Deus Pai, Criador de tudo, a Deus Filho, Salvador da humanidade, e a Deus Espírito Santo, Vivificador de todas as coisas. Neste quadro, o Cristianismo estará certamente em grau de fundar uma ética ecológica sem, porém, esgotar-se nela. E mesmo porque, a ética que nasce tendo Cristo como Alfa e Ômega da criação do Pai, pela ação do Espírito Santo, está fundada sobre a esperança da ressurreição última. Um futuro verdadeiramente novo só pode ser acolhido confiando-nos, entregando-nos à contingência de frágeis, provisórias, mas reais antecipações interpretadas à luz da fé bíblica e não à dialética e à potencialidade de uma mítica natura mater.

É necessário, portanto, dar prioridade ao futuro de Deus, que cria a história a partir dos tempos últimos e a solicita, insistentemente, a um destino de vida reconciliada, que envolve não só a humanidade, mas o ecossistema com suas leis evolutivas. Estas, como figuras da vida em plenitude, nos deixam entrever a nova criação trazida por Cristo, e nos aproximam cada vez mais, dos céus novos e a terra nova.

A esperança que o Cristianismo nos dá num futuro de reconciliação do ser humano com toda a natureza, com todo o cosmo, não se funda, portanto, sobre a ânsia e o desejo ardente do ser humano somente, nem sobre as suas surpreendentes descobertas através da ciência e da técnica, ou sobre o seu projeto pessoal, nem sobre a garantia ético-moral da humanidade, mas se funda sobre a iniciativa e sobre o dom de Deus.

Esta esperança traz enxertada dentro de si um sentido pleno da criação e da história, pela força do Espírito de Cristo. Suscita as suas antecipações que não consistem só no culto, mas também nos gestos e realizações concretas de vida renovada na relação com as coisas criadas do universo e na relação de uma vida de irmandade entre os humanos, quando se vive num mundo de violências contra o cosmo e contra a própria pessoa. O Pai Nosso é o exemplo mais belo que sustenta nossa invocação de fé.

Finalmente, o cristianismo nasce da fé que nos traz uma esperança aberta a um futuro que nenhuma outra religião é capaz de fazê-lo. É a prática desta fé que nos permite estarmos sempre reconciliados com a vida humana e cósmica, pois, cultivar e reverenciar tudo o que tem vida, remete ao valor supremo e absoluto da fonte da vida, que veio a nós em seu mistério, para que pudéssemos entrar em comunhão com Deus, Fonte da Vida Verdadeira.

Rev. Pistis Prax., Teol. Pastor., Curitiba, v. 1, n. 2, p. 317-338, jul./dez. 2009 


\section{Referências}

AA.VV. Il corpo alla prova dell'antropologia cristiana. In: Associazione Teológica Italiana (ATI). Fórum Ati 4, Milano, 2007.

AA.VV. Futuro del cosmo futuro dell'uomo. Padova: Messaggero, 1995.

AMATO, A. Paternitá-maternitá di Dio: problemi e prospettive. In:

Trinitá in contesto. Roma: Ateneo Salesiano, 1993. p. 237-238.

AUER, A. Interpretazione teológica dell ‘antropocentrismo. In: . Ética dell'ambiente. Brescia: Queriniana, 1987. p. 208-209.

BINGEMER, M. C. L.; FELLER, V. G. Deus-amor: a graça que habita em nós. São Paulo: Siquem, 2003. p. 142-143.

BLANK, R.; VILHENA, M. A. Esperança além da esperança. Madrid: Siquem, 2001.

BOFF, C. Como vejo a teologia Latino-Americana trinta anos depois. In: SUSIN, L. C. O mar se abriu: trinta anos de teologia na América Latina. São Paulo: Loyola, 2000. p. 79-96.

BOFF, Leonardo. O evangelho do Cristo cósmico: a realidade de um mito: o mito de uma realidade. Petrópolis, Vozes, 1971.

. Jesus Cristo libertador. Petrópolis: Vozes, 1972.

. A trindade, a sociedade e a libertação. Petrópolis: Vozes, 1986.

Ecologia: grito da terra, grito dos pobres. São Paulo: Ática, 1995.

. Ética da vida. Brasília: Letraviva, 1999.

BOFF, Lina. Da protologia à escatologia. In: MÜLLER, I. (Org.). Perspectivas para uma nova teologia da criação. Petrópolis: Vozes, 2003. p. 11-130.

A concepção de vida em Gregório de Nissa: ensaio de aproximações com as ciências da vida (parte II). Atualidade Teológica, n. 29, p. 137-168, 2008.

. Spe salvi e Vaticano II. REB, n. 271, p. 653-670, 2008.

Rev. Pistis Prax., Teol. Pastor., Curitiba, v. 1, n. 2, p. 317-338, jul./dez. 2009 
BORDONI, M. L'orizzonte cristocêntrico della creazione. In: SESBOÜÉ, Jésus Christ lùnique médiateur. Les récits du salut. Paris: Desclé, 1991. p. 421.

. Gesú di Nazaret II. Brescia: Queriniana, 1995.

. Tempo, spazio, nell‘escatológico Cristiano. Orizzonti attuali della rifessione teológico-sistemática sulla escatologia. In: AA.VV. Escatologia e liturgia. Aspetti escatologici del celebrare Cristiano. Roma: CLV, 1993.

. Parusia e palingênensi. In: BORDONI, M. Gesù di Nazaret, III. Brescia: Queriniana, 1995.

COLOMBO, G. Creazione. Nuovo Dizionario di Teologia. Alba: Paoline, 1977. COMBLIN, J. Antropologia cristã. Petrópolis: Vozes, 1990.

DIANICH, S. Antropocentrismo e fede cristiana. Uma questione da riaprire. In: __ La creazione oltre l'antropocentrismo? Padova: Messaggero, 1992. p. 28-41.

FABRIS, R. Dizionario Bíblico storico/critico. Roma: Borla, 1987. p. 301-302. HAFFNER, P. Il mistero della creazione. Cittá del Vaticano, 1999.

MOLTMANN, J. Dio nella creazione: dottrina ecológica della creazione. Brescia: Queriniana, 1986.

- Teologia da esperança: estudos sobres os fundamentos e as conseqüências de uma escatologia cristã. São Paulo: Loyola, Teológica, 2005. 1999.

. O espírito da vida: uma pneumatologia integral. Petrópolis: Vozes, MURATORE, S. Oltre l'antropocentrismo cosmológico. In: STAGLIANÒ, A. La creazione l'uomo. Padova: Messaggero, 1992. p 244-258.

REIMER, H. Toda a criação. Bíblia e ecologia. São Leopoldo: Oikôs, 2006. REIMER, H.; SILVA, V. da. (Org.). Libertação, liberdade: novos olhares. Associação Brasileira de Pesquisa Bíblica, em seu II Congresso Brasileiro de Pesquisa Bíblica. Goiânia, Universidade Católica de Goiânia; São Leopoldo: Oikós, 2008. 
RODRIGUES da CRUZ, E. A dupla face: Paul Tillich e a ciência moderna: ambivalência e salvação. São Paulo: Loyola, 2008.

TERRIN, A. N. Dio nella new age, e nella sensibilitá contemporânea. In: . Dio, mondo, natura. Padova: Messaggero, 1991. p. 139-146.

TILLICH, P. Teologia sistemática: a existência e o Cristo. São Leopoldo, RS: Est e Sinodal, 2005.

TRIGO, P. Criação e história. Petrópolis: Vozes, 1988.

VANNI, H. La creazione in Paolo. In: . Rassegna di teologia/5. 1995. p. 295-299.

Recebido: 22/01/2009

Received: 01/22/2009

Aprovado: 02/05/2009 Approved: 05/02/2009

Revisado: 15/07/2009 Reviewed: 07/15/2009 